\title{
The Role of File Character in the Implementation of the Principle of Proportionality of Punishment to the Crime during the Trial Phase
}

\author{
Saemeh Ataee Ghasabe ${ }^{1}$ \\ ${ }^{1}$ Department of Law, Rasht Branch, Islamic Azad University, Rasht, Iran \\ Correspondence: Saemeh Ataee Ghasabe, Department of Law, Rasht Branch, Islamic Azad University, Rasht, \\ Iran. E-mail: Saemeh_Ataee@yahoo.com
}

\author{
Received: May 15, 2016 Accepted: June 6, 2016 Online Published: June 29, 2016 \\ doi:10.5539/jpl.v9n5p214 URL: http://dx.doi.org/10.5539/jpl.v9n5p214
}

\begin{abstract}
The principle of proportionality of punishment to the crime represents completion of crime law for determining appropriate penalty, that is resulted from revolution of criminal justice in the way to considering the subject of criminal act and his personality. In fact, the correct response to against breaking norms needs to consider the question that "who did it" in spite of considering the act itself, it means that "what did the criminal do" or "what happened" by criminal prosecution authorities and specially courts and this time not only in terms of assign a criminal act to a person but also this means that what is the defendant's mental, physical structure and family history which could effect on his/her criminal characteristic is a necessary fact. File character that the necessity of formation was considered more in twentieth century, is called to a case that is formed besides file character and indicates information about general and special statues of criminal such as mental, family, educational and social condition. This file guide decision-makers and criminal justice to choose appropriate clinical methods and they will make appropriate criminal measures according to related information such as laboratory and conducted research in order to fulfill medical and correctness. In this research, we only study role of this file in trial phase.
\end{abstract}

\section{Introduction}

In trial phase, they will investigate indictment, the quality of crime, citation reasons, commits responsibility, the type and amount of punishment and/or security measures and finally it's proportionality with criminal's characteristic (Shamlo \& Gozley, 2011), in spite of nature and force, the judge should pay more attention to the criminal person her/himself. The principle of proportionality of crime with punishment or generally speaking "personalized criminal justice" is one of the most important principles of punishment that by following this principle, punishments will become more justice and humanistic. This means that while sentencing proceedings and by considering criminal's personality, the judge should determine criminal sanction both by means of duration and in a way that leads to her/his benefit. Therefore, forming file personality for criminal during trial phase is necessary in order to fit punishment with criminal personality. Forming this file means to ignore legal aspects of crime in order to consider humanistic aspects of crime by studying family, educational, professional, mental and physical history of criminal. The motivation to do the crime, the relation of criminal with victim, probable partners or assistants, the criminals behavior with victim after doing the crime, the criminals general condition after crime and ... (Mohammadian \& MohammadRezapour,2013).

Iranian legislator didn't predict file character during substantive proceedings frankly and in this regard criminal court doesn't have any duty to form this file. The legislator implicitly assign the judge to adjust a kind of virtual character in his mind.

\section{The Role of Personality File in Implementation of Mitigation in Performing the Principle of Appropriateness between Crime and Punishment}

Sometimes the terms of acting the crime or mental and social characteristics of criminal is in a way that it is appropriate to impose milder punishment to him/her. Both legal and judicial mitigation is one of the most effective solutions to establish the principle of appropriateness of criminal and punishment and encourage criminals to stop doing criminal acts and it's an attempt to prevent the spread of the harmful effects of crime. In addition to the statutory mitigating excuses that commutation of sentence is their coercive results. Judicial mitigation will result in commutation of punishment if the discretion of the judge. 
Matching the crime with criminal's personality and also the possibility to perform justice by considering public opinion is one of the most important effects and benefits of judicial mitigation. Thereof, mitigation is a tool to realize the principle of appropriateness of criminal and punishment, that without this principle, it's impossible to change such sentences as execution and also sentences below the minimum established by law. (Ready: 2010)

In opinion of one of Arab juristic there is no doubt that between normal and insane people, there is a group of people who are different with them in point of lack of intellect and will. For this reason, during examining these people, mental disease specialists sometimes declare that although they have will but they don't have free will. Although they aren't insane and irresponsible, therefore inherited or acquired symptoms limit or incomplete their responsibility. Especially about people like above mentioned accused people, if the judge behaves them kindly and compassionately, in fact he will make a penalty according to the principle of appropriateness of crime with punishment. After studying personality file together with criminal case, and when criminal justice knows that the committed responsibility in the case isn't general, he should make the punishment according to character of criminal person by using some devices. One of the proportionality devices is using mitigation. (Mohammad Nasl, 2004). On the other hand, mitigation let the judge to make his decision better and more logically regarding criminal's spirits and case history and motivations for making the crime. (Ardebili, 2004)

In spite of mitigating factors, performing the principle of proportionality between punishment and criminal and adapt it with criminal's character is possible without direct or indirect interference of legislator. Although, primary delegation of authority and determining delimitations is legislators duty. However, during analysis level and selecting suitable punishment, there is no need for further interference of legislator. So by using mitigation, the judge can place justice in the way of evolution and improvement according to public conscience with no legislative action and intervention. (Aliaabadi, 2003). It shouldn't have limit judges authority. But they should have power to decrease penalty as much as be compatible with real character of criminal and special condition and also leads to revise him/her and prevent recidivism and furthermore fairness based on public conscience. Paying enough attention to the role of public opinion for determining penalty shows that it is necessary to have mitigation and giving power and authority to judge. In events that public opinion injured badly and all people tent to the necessity of lower the penalty for a special crime. Immediate and on time reaction of legislative sometimes is an offbeat and unreasonable request. In such situation, by using legal authorities and mitigation, the judge starts to fit the penalty and satisfy public expectations and in determining the penalty keep in mind the public opinion. (Ready, the same)

In spite of effective and unavoidable role of mitigation in order to lower and make it proportion, according to article 37 Gh.M.A using it is completely optional and depends on the court. (The same, page) However, it seems that we should leave the appearance and interpret phrase "it can" as "phrase it can" in the test of article doesn't mean that legislator concede everything to personal point of view and the judge. Such interpretation is against mitigation factor and penology. But also it should be allowed to believe that in order to performing and the principle of personalization of punishment the legislator asks judges to study the case that legislator was unable to do, make the mitigation factors and do it and this apparently optional matter in fact is an obligatory expectation. (Mosavi Beigy, 2012)

As a result, as stated, judicial mitigation is a situation that the criminal deserves leniency in eyes of the court, as the judge convince to determine his/her punishment lower than minimum legal punishment. Regarding the fact that as one aspect of lowering the punishment is special condition of character and his/her background, this matter exactly shows the necessity to recognize criminal's character and from file character for lowering the punishment. On the other hand, although legislator doesn't explain the meaning of criminal's special condition and/or his/her background in paragraph 5 of this article clearly, but what comes to mind is the fact that legislator means the situation of that person in society and the specific circumstances of his/her life and character. Moreover, in article 38 paragraph 3 of Islamic punishment legislator assigns the judge to consider intention, his/her mental situation during crime commitment and family and social history and effect of Taazir on it and implicitly mention forming file character when issue punishment sentence, but the legislator haven't determined how to do it. While it is expected that the legislator used criminology findings and use of modern methods and determine tools and indexes of forming file character. (Shamloo, Goozley, 2011)

\section{The Role of File Character for Doing Aggravating Qualities in Performing the Principle of Proportionality between Punishment and Crime}

The intensification of punishment means to punish a crime legally and directly by legislator or judge. Intensification of punishment may become as increase level of punishment, increase number of punishment, change to sever punishment, add subdominant punishment and/or delegation of authority to the judge in order to 
do additional punishment and so on. Sometimes criminal act is more dangerous for society and/or makes more sense and/or the criminal have some characters that it seems that he/she should punish severely. Aggravating qualities is divided to several parts and includes A. legal and judicial aggravating qualities. B. personal and foreign aggravating qualities. C. general and specific aggravating qualities.

The aspects of legal aggravating necessarily must mention in law, if not the punishment cannot be intensified, in spite of being very dangerous and judge find it necessary to intensify the punishment. In fact, legal aggravating punishment is limited to written legal articles and legislator can't increase or decrease some other aspects as aggravating qualities. Therefore, the judge implements the law, if there are aggravating similarities. It means that judge adapts subject of dispute with law and then determine suitable punishment. A legal aggravating quality is against judicial aggravating qualities. Judicial aggravating qualities contains special situation by which the legislator implicitly or explicitly forces the judge to perform sever punishment. From the view point of intensifying judicial, the judge directly proceeds to aggravate criminal's punishment according to the principle of proportionality between punishment and criminal. It is necessary to mention when speak about the proportionality between punishment and criminal, we shouldn't focus on moratorium in favor of criminals and define the principle of proportionality in words such as lower, abeyance, parole and remittal, on the other hand criminal equation always doesn't like to lower the criminals punishment by using the principle of proportionality between punishment and criminal, but sometimes according to the situation and studying file character of criminal and obtained results it is necessary to aggravate punishment or change to a punishment which have enough efficiency in order to avoid to do the crime again and inform the criminal. Unfortunately, this is the fact that is mentioned fewer in law. This problem is observed less in countries that doesn't have written law and the judge him/herself decided about the punishment according to criminal's character or even in countries such as France which has written law and some other countries because of variety of punishment, the judge has less problems for determining suitable punishment. But unfortunately in our country, if the judges decided to appropriate punishment with criminal's character by aggravating punishments, they will face so many problems. In this regard, in previous Islamic punishment, approved in (2001) legislator stated about recidivism that "everyone who is sentenced to castigation punishment by court, if commit to chastisement crime again, the court can intensify castigation punishment if necessary."

As seen in this article, legislator had let the judge to intensify punishment if do the crime again and justice could aggravated or dissuade punishment, nevertheless, by approved Islamic punishment law in 2013 under subject of recidivism and by approving article 137 , legislator charged judge to intensify punishment if the criminal do the crime again. This article states that" everyone who pursuant to a final judgement in one of castigation punishment sentences of one to six convicted and from the date of judgement until or inclusion over time of performing punishment, committed another one of crimes from level one to six, will sentence to maximum of one half of previous punishment."

As seen in previous article, in the event that the criminal commit the crime again, the punishment must intensify and judge don't have any authority in this regard, while in previous law about repeating the crime the judge didn't obliged to aggravate punishment if do the crime again.

Therefore for performing the principle of proportionality between punishment and criminal and considered minimum and maximum punishment in law, judicial judge acts to equate punishment with criminal. In fact, in each case after studying situation and criminal's condition, judge determine an appropriate punishment that is sometimes equal with an aggravating punishment. Consequently, it is clear that forming file character plays fundamental role to guide and help the judge in order to determine a punishment suitable for criminal's character in performing the principle of proportionality of punishment with criminal by aggravating. For example when in article 652 A.D (chastisement) legislator predicted two to three months prison for robbery to assault and/or armed robbery, in fact the authority to aggravate punishment for this duration (three months to ten years) is belonging to judge so that he act to aggravate punishment based on situation and studying file character if think that it is right and according to proportionality of punishment with criminal.

\section{File Character and Its Role in Punishment Abeyance in Performing Proportionality of Punishment with Criminal}

Abeyance punishment has a close relation with file character and there is no doubt that making decision about issue and grant abeyance or not to issue it for criminal needs to form file character. On the other hand, criminal justice fundamentally will face serious problem without such file and without studying it's containing- as mentioned earlier. Because according to article 46 GH-M-A criminal's punishment abeyance is possible under condition that the condition considered in article 40 GH.M.A which are predicted have prepared. It includes 
consider personal, family and social condition and history and situation which lead to commit the crime.

In another word, during criminal trial, not only criminal acts but also criminal him/herself should have considered. On the other hand, guarantee to perform should be consistent with criminal's psychological and real character moreover criminal's legal personality. Article 46 of Islamic punishment approved in 1392 stated that:

The condition to abeyance the verdict which is predicted in article 40 GH.M.A includes criminal's experiences, family and social situation and so on. In issuing all these items, it is necessary to form and arrange file character and use it to issue punishment implicitly.

The question that comes to mind here is how will the criminal judge inform about criminal's social condition and life experiences and situation that leads to do the crime? Do not filing character force implicitly? It seems that legislator mentioned the role and necessity to form file character by using the phrase "above mentioned" and considering social condition and life experiences of criminal are all duties that law leaves for court to do them. But in fact and presently, according to present situation, the judge doesn't have necessary preliminaries and tools to inform about them.

Therefore, in Iran's criminal system, mention criminal's character was discussed to abeyance punishment, but Iranian legislator only mentioned it in articles 40 and 46 in general. In fact, although legislator mentions the necessity to form file character, but also didn't pay enough attention to necessary tools to form it.

\section{File Character and Its Role in Delay Sentencing Punishment in performing the Principle of Proportionality between Punishment and Criminal}

In some cases, the acted crime isn't so repulsive and dangerous that it needs to punish certainly in eyes of public opinion. Furthermore, regarding criminal's feelings and mental situation it becomes obvious that threat to do punishment will be more effective than punishment itself in her/his impulsive behavior. On the other hand, it is possible that if criminal send to prison environment, not only punished but also learn some other criminal behavior there and will do more crimes by personalized these behaviors. In such situation, there is no doubt that it will be better to delayed punishment by promise to respect all laws and regulations and legal predictions according to lessons of principle of proportionality between punishment and criminal and this will be in more favor of criminal and society. (Natery, Kalantari, Zaree, 2013)

In Iran's penal system according to article 374 A.D.K judge should declare his opinion at first possible chance and approximately during one week. And he doesn't have any authority to delay it. However, authority to delay sentence and not determining punishment after finishing research and authentication of be criminal was predicted in Islamic punishment law issued in 2013 in accordance with policies of proportionality between punishment and criminal. In article "40" of this law the trial has right to delay issuing punishment for six months to two years in crimes level six to eight if there are ways to lower punishment, behave correctly, compensate costs or make condition to compensate and finally don't have any criminal experience by considering personal, family and social situation and experiences and situation which led to do the crime. This article which is invented in new Islamic law is a beneficial tool to proportionate criminal's punishment, because especially for girls and boys and women who may summoning to judicial authorities and law enforcements, if arrested, families may angered them and so they prefer to run (Goldozian, 2013). Therefore, it's better to use possibilities to delay sentencing punishment to personalized penalty. In this regard, file character is a tool that helps judge to delay sentencing penalty.

\section{File Character and Its Role in Judicial Breaks in Performing the Principle of Proportionality between Punishment and Criminal}

Judicial break is another way that magistrate can use to proportionate punishment with criminal's character. In another word, judicial break from punishment is a special kind of tools to executive principle of proportionality between punishment and crime. This legal establishment was extracted from France law article 59-132. (Zeraat, 2013) This leniency, that causes the criminal free from punishment is a new foundation that legislator considered in article (39) of Islamic punishment law. Judicial break means that after investigation and verification of criminality committed, if the court predicts his/her behavior modification by following necessities and commitments which made by court and the consent of the victim and compensate victim's damage, the court will declare criminal free of punishment. (Aghayee janat Makan, 2013) In article 39 of new law, despite the accused is found guilty let court declare criminal free of guilt completely. That it needs to form file character for criminal. Based on this article: " in chastisement crimes of level seven or eight, in case of obtaining lowering punishment if after finding guilty, court recognize to ameliorate without punishment and in case of lack of criminal experiences and forgiveness of complainant and compensate damages or arrange to compensate, the criminal can 
be declared free of punishment."

In relation to the history of this institution it should be said that: "establish free from punishment that already was predicted only for special situations such as crime partners and assistants in some of legal regulations as article 7 GH.M.I chastisement part and article 5 of disruptors law in aircraft flight safety, in Iran's criminal law system written in article 39 without legislative background. Because this type of exemption based on correction of criminal and decriminalization and naturally are different with that is predicted in special law. (Mosadegh, 2013) This article is according to perform the principle of punishment proportionality and avoid performing slight punishments which are the source of criminal labels on people (Mosavi Beigy) in this article legislator has delegated wide authorities to judges.

In provisions of article 39, the court only establishes individual's criminality and punishment has exempted. This matter has no conflict with the case about criminals who based on the sentence of court of the first instance or certainty of punishment sentence, appeals court have sentenced and after the ceremony by the head of the judiciary Ayatollah Khamenie has given them amnesty offer and he exempted them from punishment; because according to sentence in article 39, court just investigate about criminality and exempted criminal from punishment, while based on condition made about exemption, criminal should convict and then to be within the scope of article 110 of the constitution. However it should be said that this article is a step forward in the way to perform the principle of proportionality between punishment with criminal and follow the policies of imprisonment. Article 39 GH.M.A has an important term about nature of crime and legislator also has predicted another term that if all these terms fulfilled, the magistrate can act to exempt individual from guilt.

As a result, forming file character is necessary in acts of this institute, in fact especially in actions of this judicial institute, qualifying including forecast and cure the criminal, establish mitigating of the judge needs to study criminal's character that this matter doesn't fulfill without reference to file character.

\section{File Character and Its Role in Doing Alternative Punishments to Perform the Principle of Proportionality between Punishment with Criminal}

Correction and cure movement focus more on prison as criminal's clinic and it's a place to perform rehabilitation programs. However, nowadays from the view point of criminology, there are so many doubts and questions about correction function of prison and so many different criminology and cognitive problems have declared about it which clears the disability of prison to rehabilitate prisoners and also failure to fulfill goals of the principle of proportionality between punishment with criminal (that is correction and rehabilitation), in contrast it has negative function as crime institute to teach criminal behavior.

The most important objections which are stated about prison include:

1) Increase danger of released criminals

2) social exclusion ad unemployment

3) Accumulation of labor in society

4) Recidivism

5) Prison population density and increase government costs

Moreover these objections, can be mention behavioral corruption of prisoners, ruin responsibility of prisoners, decrease hygiene and moral, not to compensate wrong issued verdicts, conflict with the principle of personal punishment of prison (Babayee, Gholami, 2012) all these problems are matters that the principle of proportionality of punishment with crime tries to destroy them by proportionality of punishment with character, situation of crime and etc....

Therefore, according to inefficiency of prison punishment to rehabilitation of prisoners, prison alternative programs seem necessary and useful (haji Tabar Firoz jani, 2008) Accordingly, nowadays Iranian policy makers and also other countries act to write laws under the subject of prison alternative punishments in order to de imprisonment and avoid use of prison punishment at first stage and proportionate punishment with criminals character at second stage

In fact, because prison alternatives are various and make this possibility for judges to sentence a punishment proportional with criminals situation regarding situation and criminals character, so it's an appropriate field to apply the principle of proportionality between punishment with criminal so that they can act to proportionate punishment with criminal by these alternatives. Using this factor needs to form file character. 


\section{Conclusion}

Nowadays, paying attention to criminal's character and situation effective on crime is one of the main challenges of system of criminal justice. Classic school that only paid attention to done action means crime didn't consider the criminal's mental and physical aspects, for this single reason it criticized severely. Stated criticizes lead Bakaria and Bentam to found a new doctrine and made a huge revolution in criminal law at the end of 18 century. The principle of proportionality between punishment with criminal suggested by Bentam and at first used in France law, however this principle should related to Neoclassic school and Reymond Sally the writer of "The principle of personalize punishments". Nowadays, above mentioned principle made his place in all legal systems and legislators used different tools in this regard. On the other hand, the importance of this principle place it besides other important criminal law principles and the necessity of attention to advises of this principle and its effectiveness on improving criminal modification made use of this principle in all stages of fight with crime and criminal unavoidable.

The principle of proportionality between punishment with criminal that is one of important principles ruled over punishments resulted more humanistic and more equitable punishments. This principle in extended meaning includes act and perform punishments proper to individuals character, and social, mental and physical characteristics which is predicted by legislator based on nature of crime or characteristics of criminal and through the judiciary and the executive come to fruition and it may leads to intensify or decrease and suspend ... of punishment. On the other hand, above mentioned principle means that judge acts to form file character besides criminal file and after studying criminal's personal history and get the expert opinions of scientists of different sciences and measure health condition of criminal and his/her share of doing the crime and finally find real character of criminal make best decision according to personal characters, in a way that leads to modify and cure and rehabilitation and return him/her to society and family.

\section{References}

Aghayee janat Makan, H. (2013). General Criminal Law (New Criminology) (1st ed.). Tehran, Jungle Publication.

Ali Abadi, A. (2013). Criminal Law (Vol 2, 1st ed.). Tehran, Ferdowsi Publication, First Print, (2003).

Amadeh, G. (2010). Judiciary Authorities in determining Punishment (1st ed.). Tehran, Dadgostar Publication.

Ardebili, M. A. (2009). General Criminal Law (Vol. 1). Tehran, Mizaan Publication, Twenty Two print.

Babayee, M. A., \& Gholami, M. (2012). Most important Features of Decriminalization in New Islamic Law. Journal of Legal Thought, International Quazvin University, First Year, 3.

Goldozian, I. (2013). Mahshaye Islamin Penalty Code (2nd, ed.). Tehran, Majd Publication.

Haji Tabar, F., \& Jani, H. (2008). Alternatives of Prison in Iran's Criminal Justice. Justice Law Journal, (64).

Mohammad Nasl, G. (2004). Practical Study of Suspended Punishment in Criminal Law and Procedure of Iran Courts. The Magazine of Law and Political Science Faculty (Tehran University), (64).

Mohammadian, S., \& Mohammad Reza pour, B. (2013). The necessity of forming file character during criminal legal proceedings in Iran. Scientific Magazine of Legal Medecine, 19(2/3).

Mosadegh, M. (2013). The Description of Islamic law Punishment (3rd ed.). Tehran, Jungle Publication.

Mosavi Beigy, S. A. (2012). Modifying and Converting a Penalty in the Iranian Legal System and its Challenges. Excellent Law quarterly, New period(1).

Pak Nahad, A. (2009). Risk-Based Criminal Policy (1st ed.). Tehran, Mizan Publication.

Shamloo, B., \& Goozley, M. (2011). File Character in Criminal law of Iran and France. Criminal law lessons, New $\operatorname{period}(2)$.

Shams Nutery, E., \& Kalantari, H. R. (2013). Islamic law in Present Order (1st ed.). Tehran, Mizan Publication.

Zeraat, A. (2013). A Brief Description of Islamic Law Punishment (Vol. 1, 1st ed.). Tehran, Ghoghnoos Publication.

\section{Copyrights}

Copyright for this article is retained by the author(s), with first publication rights granted to the journal.

This is an open-access article distributed under the terms and conditions of the Creative Commons Attribution license (http://creativecommons.org/licenses/by/3.0/). 